\title{
16. 冠動脈疾患の診断と治療：最近の進歩
}

\author{
和歌山県立医科大学循環器内科 赤阪 隆史
}

冠動脈疾患の診断は基本的に心筋虚血の「存 在」診断と「部位」診断によってなされている. 従来, 心筋虚血の有無は負荷心電図や心筋シン チグラフィーなどの生理機能学的検査で, 最終 部位診断は冠動脈造影に代表される解剖学的検 查法で評価されてきた。 しかし, 近年の検査法 の発達により，生理機能学的検査ではドブタミ ン負荷心エコー図や冠血流計測, 冠内圧計測, MRIによる心筋灌流イメージを用いた心筋虚血 の診断が普及しつつある. また, 解剖学的検査 法ではMDCTやMRIを用いた解剖学的診断が急 速に進歩し, 外来で非侵襲的または半侵襲的に 詳細な解剖学的評価が可能となってきている. また, 血管内イメージング装置も進歩し, 従来 の血管内超音波や血管内視鏡に加えて, 近赤外 線を用いた光干渉断層法（OCT）が使用される ようになり, 10〜 $15 \mu \mathrm{m}$ の解像度で血管壁やプラー クを観察し, 急性冠症候群などの動脈硬化やス テント血栓症などの病態生理解明に寄与してい
る.このように, 冠動脈疾患の診断法は, 非侵 襲・低侵襲という方向と詳細な観察という両方 向に進歩してきている.

冠動脈疾患の治療では, 薬剂溶出性ステント (DES)の出現により, インターベンション後の 再狭窄の問題が克服されつつあるが, 遠隔期血 栓症や薬剂副作用などの問題が新たに発生して いる．冠動脈バイパス術も人工心肺を用いない off-pump bypassも定着し, 従来のon-pump bypassとの使い分けもなされている. しかし, 急性 冠症候群の予測・予防は今なお困難で, スタチ ンやARB・ACEIをはじめとする血管内皮保護作 用のある薬剂を用いた一次予防・二次予防の重 要性が確認されてきている. また, 急性冠症候 群の発症が不可避と考え, 再生医療による血管・ 心筋再生に関する研究も進歩し続けている.

このような現状を背景に, 冠動脈疾患の診断・ 治療の最近の進歩と今後の可能性について解説 する.

\section{7. 抗菌化学療法のPK/PD分析による適正化}

\author{
昭和大学医学部臨床感染症学 二木 芳人
}

過去の抗菌化学療法は慣例的かつ画一的で, 個々の感染症例に応じた適正な薬剂選択と使用 が行われてきたかは疑問である，それでも優れ た抗菌薬が数多く臨床使用できた状況では, 大 きな問題とは理解されず，また，臨床効果もそ れなりに得られてきた。しかし，そのような抗 菌薬使用が耐性化を助長し, 医療経済的な損失 を生んできたことも事実であろう。近年各種感 染症に揸いて耐性菌が急増し, それに立ち向か
うべき新規抗菌薬の開発の停滞が続くなか, 必 然的に求められるようになったものが適正抗菌 薬使用であり，その一つの手段として応用され ているのが $\mathrm{PK} / \mathrm{PD}$ 分析である.

$\mathrm{PK} / \mathrm{PD}$ 分析の手法は欧米では以前から常識的 に日常臨床で用いられており, 単純に論ずれば, 抗菌薬の作用特性に応じて抗菌薬を濃度依存的 殺菌グループと時間依存的殺菌グループとに区 別し, 夫々の特性を活かした使用法と現状に応 